\title{
Skin Adnexal Tumors: A Histopathological analysis of 30 Cases at a Tertiary Care Centre
}

Divya Tejaswi Gopidesi (MD) ${ }^{1}$, P Viswanath Sai (MD) ${ }^{1 *}$, Shanthi Vissa $\mathrm{MD}^{2}$, Saumya Bandla ${ }^{1}$, B V Hari Charan ${ }^{1}$, Nandam Mohan Rao $\mathrm{MD}^{2}$, Byna Shyam Sundara Rao $\mathrm{MD}^{2}$, E. Bhavana Grandhi $\mathrm{MD}^{3}$, Vijaya lakshmi Muram Reddy $\mathrm{MD}^{3}$, Raguraman Sujitha $\mathrm{MD}^{4}$, G.V.Sunanda Lakshmi MD

${ }^{1}$ Post Graduate, Department of Pathology, Narayana Medical College and Hospital, Nellore, Andhra Pradesh, India

${ }^{2}$ Professor, Department of Pathology, Narayana Medical College and Hospital, Nellore, Andhra Pradesh, India

${ }^{3}$ Associate Professor, Department of Pathology, Narayana Medical College and Hospital, Nellore, Andhra Pradesh, India

${ }^{4}$ Assistant Professor, Department of Pathology, Narayana Medical College and Hospital, Nellore, Andhra Pradesh, India

DOI: $10.36348 /$ sjpm.2020.v05i02.005

| Received: 28.01.2020 | Accepted: 04.02.2020 | Published: 14.02.2020

*Corresponding author: Dr. P Viswanath Sai

\section{Abstract}

Background: Diagnostic challenges are associated with skin adnexal tumors because of a broad spectrum of tumor and tumor-like lesions along with their histological variants, the degree of differentiation, the rare incidence of few of these tumors, and the complex nomenclature. The aim of this study is to study the spectrum and microscopic features of Skin adnexal tumors. Methods: A prospective study was conducted over a period of 2 years from August 2017 to July 2019 in the Department of Pathology, Narayana Medical College and Hospital, Nellore. Formalin fixed, paraffin embedded tissue sections were stained with Hematoxylin and Eosin. Result: Out of the total 30 cases diagnosed as Skin adnexal tumors, $15(50 \%)$ tumors were showing Eccrine differentiation followed by tumors with Pilar differentiation, 8 (26.67\%), Apocrine differentiation, $5(16.67 \%)$ and Sebaceous differentiation, $2(6.66 \%)$. The age ranged from 13 to 73 years and male to female ratio was $1.14: 1$. Most of the tumors were benign, 29 cases $(96.67 \%)$ while only 1 case $(3.33 \%)$ was malignant. Clear Cell Hidradenoma was the most common tumor. Conclusion: Morphological features and identifying the path of differentiation are of great importance in diagnosing Skin adnexal tumors.

Keywords: Skin adnexal tumors, histopathology, eccrine, apocrine, pilar, sebaceous.

Copyright @ 2020: This is an open-access article distributed under the terms of the Creative Commons Attribution license which permits unrestricted use, distribution, and reproduction in any medium for non-commercial use (NonCommercial, or CC-BY-NC) provided the original author and sources are credited.

\section{INTRODUCTION}

Skin adnexal tumors are the tumors arising from skin appendageal structures such as sebaceous glands, sweat glands, and hair follicles. They are usually difficult to diagnose clinically, and histopathology confirms diagnosis. Skin adnexal tumors are typically sporadic: however, the presence of specific types of Skin adnexal tumors can be seen in some complex genetic syndromes like Muir Torre syndrome and Cowden's syndrome. ${ }^{1}$ The histogenesis of these composite tumors is still not defined; however, a pluripotent stem cell origin is suggestive. ${ }^{1}$ This study was undertaken to analyze the spectrum of skin adnexal tumors along with their histopathological profile.

\section{MATERIALS AND METHODS}

The present study is a prospective study conducted over a period of 2 years (August 2017 to July 2019) in the Department of Pathology, Narayana Medical College and Hospital, Nellore. Approval from
Institutional ethics committee was taken prior to the study. Patients with suspected Skin adnexal tumors. All the biopsies of skin adnexal tumors received from General surgery and Dermatology departments at Narayana Medical College, Nellore. The excised specimens were fixed with $10 \%$ formalin, processed and stained using Hematoxylin and Eosin before subjecting for microscopic evaluation.

\section{RESULTS}

A total of 30 patients (16 males and 14 females) with skin adnexal tumors were evaluated. The male to female ratio was $1.14: 1$. The age range of these tumors varied from 13 to 73 years. The most common age group was 31-40 and 51-60 years which made up 7 $(23.33 \%)$ cases each (Table-1). Out of the 30 cases, 29 $(96.67 \%)$ were benign while only 1 (3.33\%) was malignant. Tumors with Eccrine differentiation accounted for $15(50 \%)$ cases. $8(26.67 \%)$ cases of Pilar differentiation, $5(16.67 \%)$ cases of Apocrine differentiation and $2(6.66 \%)$ cases of Sebaceous 
differentiation was seen (Table-2). Among the benign tumors, Clear Cell Hidradenoma was the most common tumor with $9(30 \%)$ cases. Pilomatricoma was the next common tumor with $4(13.33 \%)$ cases. Hidradenoma Papilliferum, Trichilemmoma and Eccrine Poroma made up $3(10 \%)$ cases each. $2(6.67 \%)$ cases each of Eccrine Spiradenoma and Syringocystadenoma
Papilliferum was noted. 1 (3.33\%) case each of Eccrine Cylindroma, Keratoacanthoma and Sebaceous adenoma was noted. The 1 (3.335) case of malignant Skin adnexal tumor was Sebaceous Carcinoma (Table-3). Head \& Neck was the most common site with 22 $(73.33 \%)$ cases (Table-4).

Table-1: Age and Sex distribution of Skin adnexal tumors

\begin{tabular}{|c|c|c|c|c|c|c|c|c|c|}
\hline Age (in years) & $<10$ & $11-20$ & $21-30$ & $31-40$ & $41-50$ & 51-60 & 61-70 & 71-80 & Total \\
\hline Male & 0 & 0 & $26.67 \%$ & $413.33 \%$ & $\begin{array}{l}3 \\
10 \% \\
\end{array}$ & $\begin{array}{l}3 \\
10 \% \\
\end{array}$ & $\begin{array}{l}3 \\
10 \% \\
\end{array}$ & $13.33 \%$ & $\begin{array}{l}16 \\
53.33 \% \\
\end{array}$ \\
\hline Female & 0 & $13.33 \%$ & $13.33 \%$ & $\begin{array}{l}3 \\
10 \%\end{array}$ & $13.33 \%$ & $413.33 \%$ & $26.67 \%$ & $26.67 \%$ & $\begin{array}{l}14 \\
46.67 \%\end{array}$ \\
\hline Total & 0 & $13.33 \%$ & $\begin{array}{l}3 \\
10 \%\end{array}$ & $\begin{array}{l}7 \\
23.33 \% \\
\end{array}$ & $413.33 \%$ & $\begin{array}{l}7 \\
23.33 \%\end{array}$ & $\begin{array}{l}5 \\
16.67 \%\end{array}$ & $\begin{array}{l}3 \\
10 \% \\
\end{array}$ & $\begin{array}{l}30 \\
100 \% \\
\end{array}$ \\
\hline
\end{tabular}

Table-2: Spectrum of Skin adnexal tumors

\begin{tabular}{|l|l|l|}
\hline Tumor differentiation & No. of Cases & Percentage \\
\hline Eccrine & 15 & $50 \%$ \\
\hline Pilar & 8 & $26.67 \%$ \\
\hline Apocrine & 5 & $16.67 \%$ \\
\hline Sebaceous & 2 & $6.66 \%$ \\
\hline Total & 30 & $100 \%$ \\
\hline
\end{tabular}

Table-3: Types of Skin adnexal tumors

\begin{tabular}{|l|l|l|}
\hline Type of Tumor & Cases & Percentage \\
\hline Benign & 9 & $30 \%$ \\
\hline Clear Cell Hidradenoma & 4 & $13.33 \%$ \\
\hline Pilomatricoma & 3 & $10 \%$ \\
\hline Hidradenoma Papilliferum & 3 & $10 \%$ \\
\hline Eccrine Poroma & 2 & $6.67 \%$ \\
\hline Eccrine Spiradenoma & 3 & $10 \%$ \\
\hline Trichilemmoma & 2 & $6.67 \%$ \\
\hline Syringocyastadenoma Papilliferum & 1 & $3.33 \%$ \\
\hline Eccrine Cylindroma & 1 & $3.33 \%$ \\
\hline Keratoacanthoma & 1 & $3.33 \%$ \\
\hline Sebaceous adenoma & 1 & $3.33 \%$ \\
\hline Malignant & 30 & $100 \%$ \\
\hline Sebaceous carcinoma & \multicolumn{2}{|l}{} \\
\hline Total & \multicolumn{2}{|l}{} \\
\hline
\end{tabular}

Table-4: Locations of Skin adnexal tumors

\begin{tabular}{|l|l|l|}
\hline Location & Cases & Percentage \\
\hline Head \& Neck & 22 & $73.33 \%$ \\
\hline Trunk & 5 & $16.67 \%$ \\
\hline Extremities & 3 & $10 \%$ \\
\hline Total & 30 & $100 \%$ \\
\hline
\end{tabular}

\section{DISCUSSION}

Diagnostic challenges are associated with skin adnexal tumors because of a broad spectrum of tumor and tumor-like lesions along with their histological variants, the degree of differentiation, the rare incidence of few of these tumors, and the complex nomenclature [2]. A pluripotent stem cell origin is suggestive in the histogenesis of these tumors [1]. In the present study, the most frequent line of differentiation is Eccrine differentiation $(50 \%)$. These findings are consistent with Samaila et al., [3], Sahu et al., [4], Shukla et al., [5] and Sharma et al., [6].

There was a slight male preponderance with the male to female ratio of 1.14:1. Similar findings were seen in Kaur et al., [7], Sahu et al., [4], Shukla et al., [5] and Sharma et al., [6]. In the present study, site of predilection was head \& neck in $22(73.33 \%)$ followed by trunk with $5(16.67 \%)$ and extremities with $3(10 \%)$ cases. The predominance of skin adnexal tumors in head \& neck region is a well-documented fact supported by many series in literature $[1,3,4,6]$. This is due to the fact that this region is rich in pilosebaceous units, eccrine as well as apocrine glands [2]. 
Clear cell Hidradenoma is the most common benign tumor with $9(30 \%)$ cases. This is in concordance with studies of Jindhal et al., [8] and Sharma et al: however, Pilomatricoma is the most common tumor in the study of Kaur et al., [7] and Eccrine Poroma is the most common tumor in the study of Sahu et al., [4].

Microscopically, Clear Cell Hidradenoma showed nodular pattern of tumor tissue separated by fibrous septa. Within the nodule, tumor cells showed bland nuclei with abundant clear cytoplasm, and few tumor cells showed bland nuclei with eosinophilic cytoplasm (Figure-1). Eccrine Poroma showed tumor cells extending from the basal layer of the epidermis with some of the lobules showing cystic spaces containing eosinophilic material. The tumor cells were uniform cuboidal cells with round nuclei and a moderate amount of cytoplasm (Figure-2). Eccrine Spiradenoma showed sharply delineated nodules in the dermis unattached to the overlying epidermis, which are composed of aggregates of cells in sheets and cords. Some of these appeared basaloid, and some cells arranged in glandular pattern with pale nuclei and containing eosinophilic material in the centre (Figure3). Eccrine Cylindroma showed lobules and islands of tumor tissue in the dermis. Within the tumor tissue, peripheral palisading pattern of darkly stained epithelial cells with central light stained epithelial cells was noted. These lobules were separated by fibro collagenous septa showing basement membrane material (Figure-4).

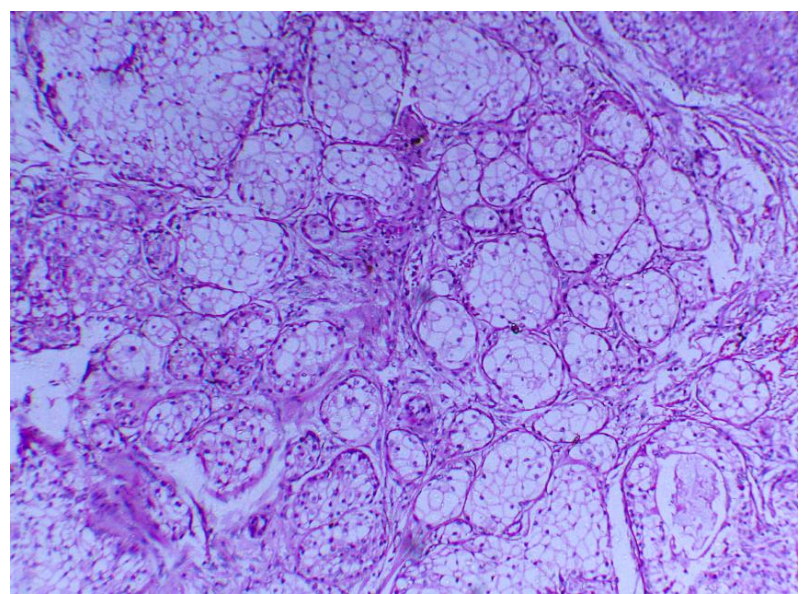

Fig-1: Nodular arrangement of tumor cells in Clear Cell Hidradenoma (H\&Ex100)

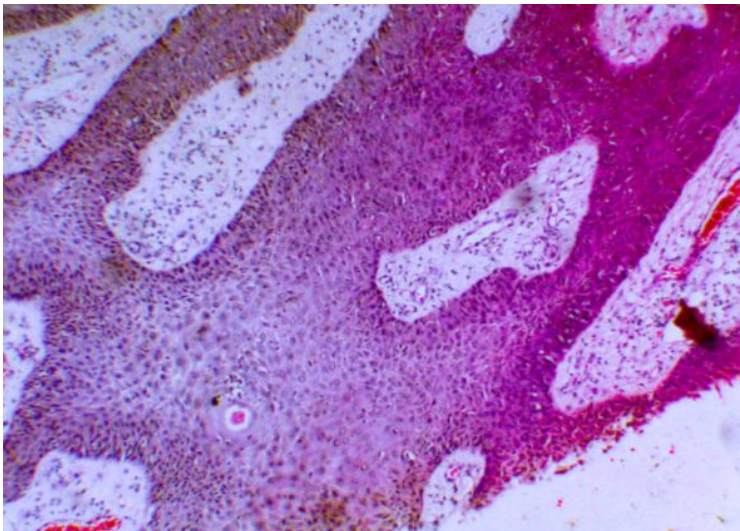

Fig-2: Eccrine poroma showing tumor cells arising from the lower portion epidermis extending downwards in broad anastomosing bands (H\&Ex100)

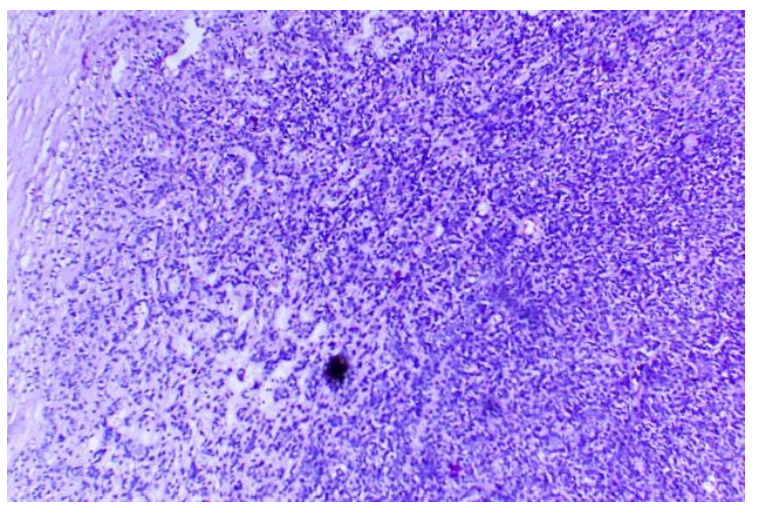

Fig-3: Eccrine spiradenoma showing tumor cells arranged in cords (H\&Ex100)

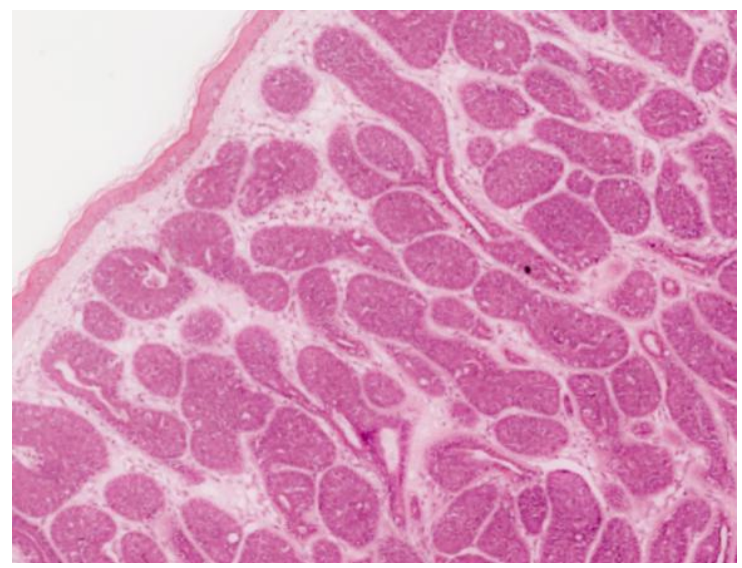

Fig-4: Eccrine cylindroma showing islands of epithelial cells of varying size and shape and lying close together $(\mathrm{H \& E}$ x100)

Pilomatricoma showed supramatrical and matrical differentiation along with areas of Ghost cells. Secondary changes like foreign body giant cell reaction and inflammation were also seen (Figures $5 \& 6$ ). Trichilemmoma showed lobules and nests of tumor cells with peripheral palisading. In a few foci, the tumor showed cells with clear cytoplasm (Figure-7). Keratoacanthoma showed epidermis with a central crater filled with laminated keratinous material and downward growth of epithelial proliferations (Figure8). 


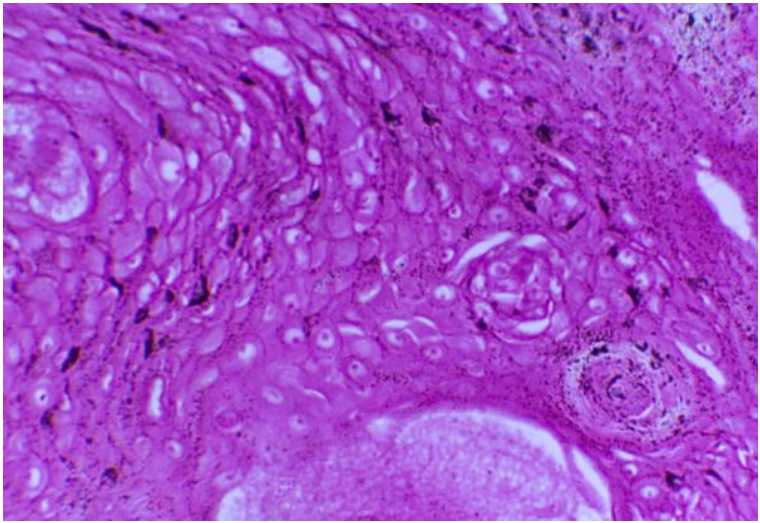

Fig-5: Pilomatricoma showing ghost cells (H\&Ex100)

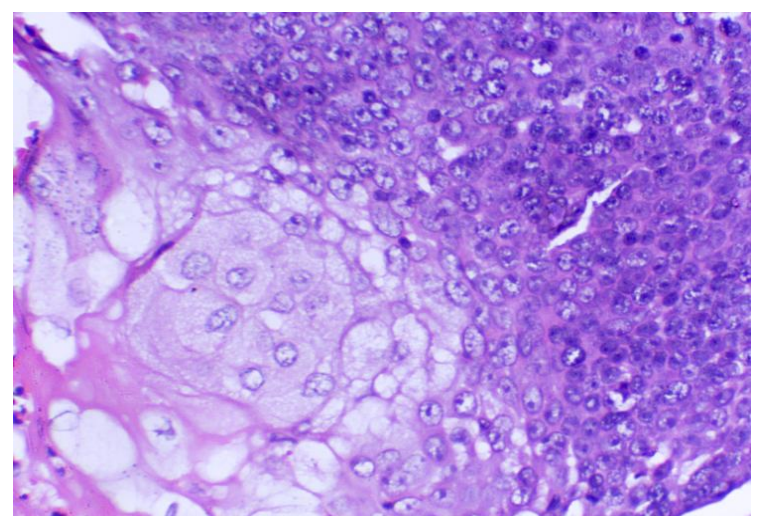

Fig-6: Pilomatricoma showing Supramatrical cells (left) and Matrical cells (right) (H\&Ex100)

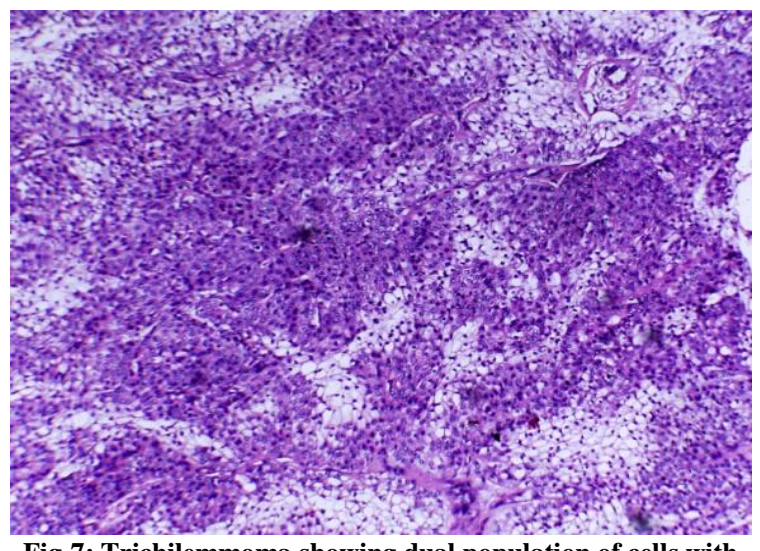

Fig-7: Trichilemmoma showing dual population of cells with eosinophilic cytoplasm and clear cytoplasm (H\&E 100X)

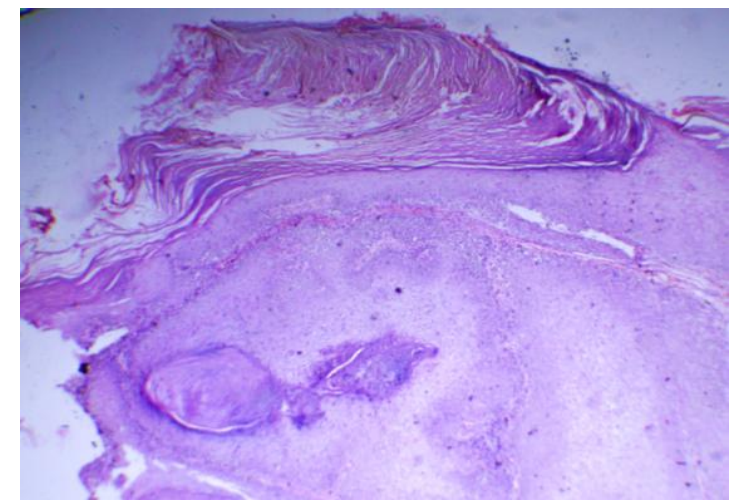

Fig-8: Keratoacanthoma showing a central crater filled with laminated keratin (H\&Ex100)
Hidradenoma Papilliferum showed a wellcircumscribed cystic lesion surrounded by a fibrous capsule in the dermis with no connection to the overlying epidermis. Both glandular and papillary patterns with papillary fronds projecting into the lumen were noted. The epithelium was bilayered with an inner layer of tall columnar cells with faintly eosinophilic cytoplasm with decapitation secretion and basal nuclei. The outer layer consisted of small cuboidal cells with brightly eosinophilic cytoplasm (Figure-9). Synringocystadenoma Papilliferum showed classic histological appearance of a papillary cystic lesion lined by two layers of epithelial cells. The outer or basal layer of the epithelium is composed of flattened or cuboidal cells and the inner layer of columnar cells. A dense plasma cell infiltrate occupied the fibrous connective tissue of the papillary stalks and dermis beneath the tumor but was most intense near the epithelium. (Figure-10).

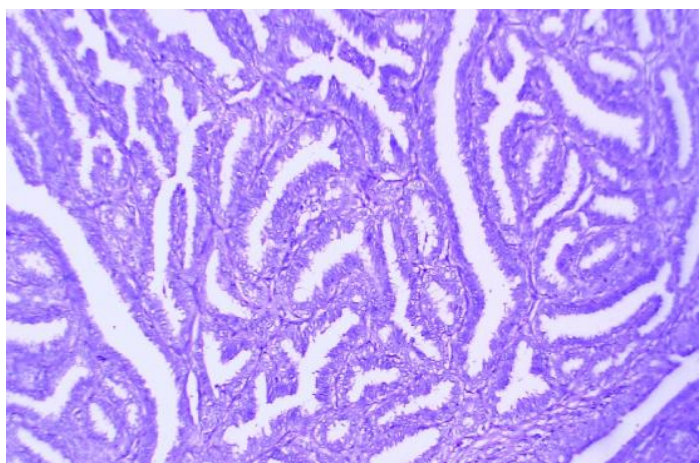

Fig-9: Papillary pattern of tumor tissue lined by double layered epithelium (H\&Ex400)

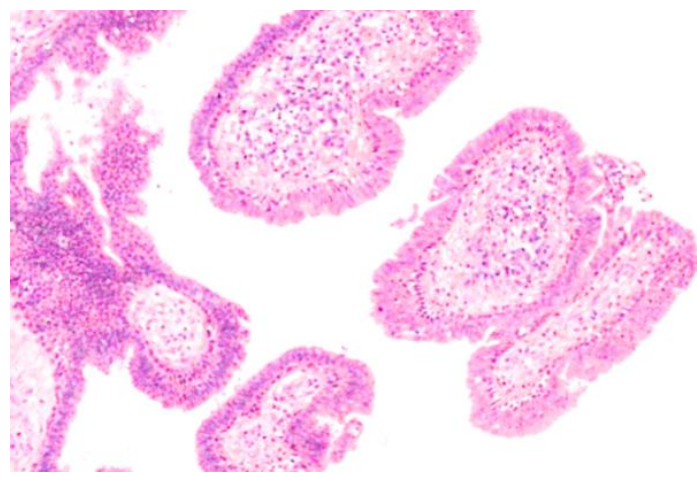

Fig-10: Syringocystadenoma Papilliferum showing papillary epithelial projections lined by a flattened peripheral layer and a columnar luminal layer with apocrine decapitation (H\&Ex100)

Sebaceous adenoma showed lobular pattern of tumor tissue in the dermis having polygonal cells showing mild pleomorphism. Within the lobular pattern, large round to oval cells with abundant foamy vacuolated cytoplasm were seen (Figure-11). Sebaceous carcinoma showed tumor tissue arranged in a lobular pattern, comedo pattern, solid nests, and papillary pattern. Individual tumor cells were round to oval with pleomorphic nuclei, prominent nucleoli, and moderate cytoplasm. Many atypical mitotic figures were also noted (Figure-12). 


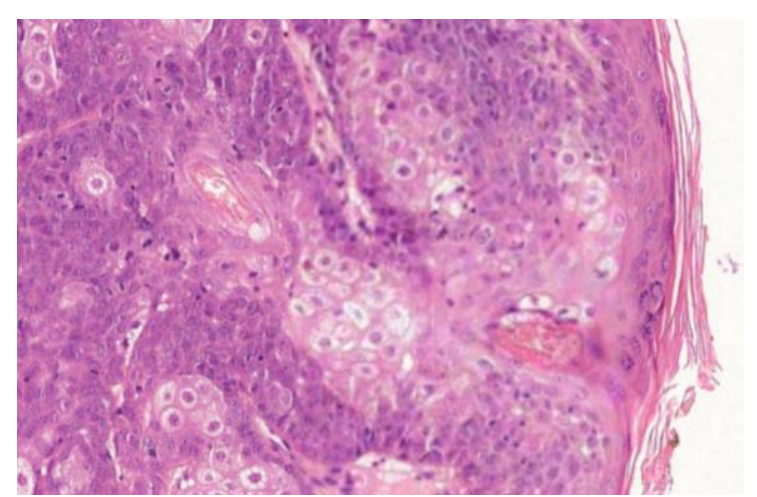

Fig-11: Sebaceous adenoma showing lobules of benign sebaceous cells (H\&Ex100)

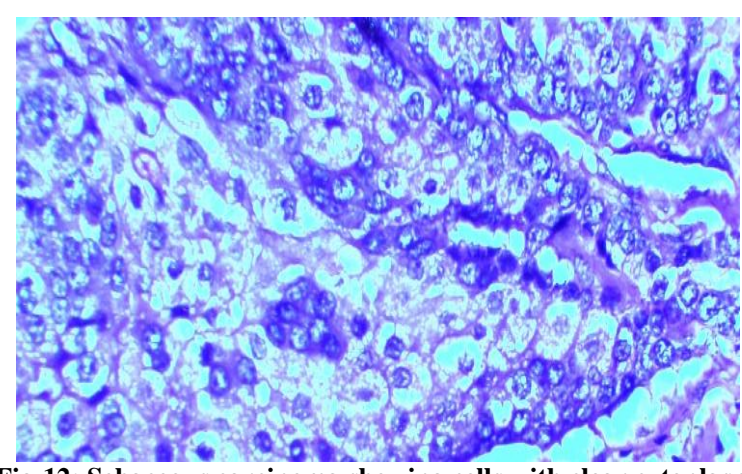

Fig-12: Sebaceous carcinoma showing cells with clear cytoplasm, pleomorphism and nuclear atypia (H\&E X400)

\section{CONCLUSION}

Skin adnexal tumors are uncommon and present diagnostic difficulties in view of the large spectrum of different lesions and their variant forms, the frequency of differentiation along two or more adnexal lines in the same lesion, and the complicated nomenclature. Most adnexal lesions are benign and, if completely excised, cause no further concern. However, diagnosing some of these lesions has clinical significance, as they might be markers for syndromes associated with internal malignancies.

\section{REFERENCES}

1. Alsaad, K. O., Obaidat, N. A., \& Ghazarian, D. (2007). Skin adnexal neoplasms-part 1: an approach to tumours of the pilosebaceous unit. Journal of clinical pathology,60(2), 129144.

2. Elder, D. E. (1997). Tumors of the epidermal appendages. Lever's Histopathology of the Skin: 747-804

3. Samaila, M. O. (2008). Adnexal skin tumors. Annals of African medicine, 7(1), 3-10.

4. Sahu, A., Sa, D. K., Naik, S. K., \& Agrawal, K. C. (2018). Skin Adnexal Tumors: A histopathological study of 60 cases at a tertiary care centre. Annals of Pathology and Laboratory Medicine, 5(3), A215-220.

5. Shukla, P., Fatima, U., \& Malaviya, A. K. (2016). Histomorphological and Immunohistochemical Reappraisal of Cutaneous Adnexal Tumours: A Hospital Based Study. Scientifica, 2016.

6. Sharma, A., Paricharak, D. G., Nigam, J. S., Rewri, S., Soni, P. B., Omhare, A., \& Sekar, P. (2014). Histopathological Study of Skin Adnexal Tumours-Institutional Study in South India. Journal of skin cancer, 2014.

7. Kaur, K., Gupta, K., Hemrajani, D., Yadav, A., \& Mangal, K. (2017). Histopathological analysis of skin adnexal tumors: A three year study of 110 cases at a tertiary care center. Indian journal of dermatology, 62(4), 400.

8. Jindal, U., \& Patel, R. (2012). Study of adnexal tumors of the skin: A three year study of 25 cases. The Internet Journal of Pathology, 13(3). 